Article

\title{
The Performance and Exhaust Emissions of a Diesel Engine Fuelled with Calophyllum inophyllum-Palm Biodiesel
}

\author{
Natalina Damanik ${ }^{1}\left(\right.$, Hwai Chyuan Ong ${ }^{2, *}\left(\mathbb{C}\right.$, M. Mofijur ${ }^{3, *}$, Chong Wen Tong ${ }^{2}{ }^{(}$, \\ Arridina Susan Silitonga ${ }^{4} * \mathbb{B}$, Abd Halim Shamsuddin ${ }^{5}$, Abdi Hanra Sebayang ${ }^{4}$, \\ Teuku Meurah Indra Mahlia ${ }^{3} \mathbb{D}$, Chin-Tsan Wang ${ }^{6}$ and Jer-Huan Jang ${ }^{7}$ \\ 1 Perusahaan Listrik Negara, The Indonesia State Electricity Company, Jakarta 12160, Indonesia; \\ natalinadamanik@gmail.com \\ 2 Department of Mechanical Engineering, Faculty of Engineering, University of Malaya, \\ Kuala Lumpur 50603, Malaysia; chong_wentong@um.edu.my \\ 3 School of Information, Systems and Modelling, Faculty of Engineering and Information Technology, \\ University of Technology Sydney, Sydney, NSW 2007, Australia; TMIndra.Mahlia@uts.edu.au \\ 4 Department of Mechanical Engineering, Politeknik Negeri Medan, Medan 20155, Indonesia; \\ abdisebayang@yahoo.co.id \\ 5 Institute of Sustainable Energy, Universiti Tenaga Nasional, Kajang 43000, Selangor, Malaysia; \\ abdhalim@uniten.edu.my \\ 6 Department of Mechanical and Electro-Mechanical Engineering, National Ilan University, Yilan 260, Taiwan; \\ ctwang@niu.edu.tw \\ 7 Department of Mechanical Engineering, Ming Chi University of Technology, New Taipei City 243, Taiwan; \\ jhjang@mail.mcut.edu.tw \\ * Correspondence: onghc@um.edu.my (H.C.O.); mdmofijur.rahman@uts.edu.au (M.M.); \\ arridina@polmed.ac.id (A.S.S.); Tel.:+61-46985-1901 (M.M.)
}

Received: 31 July 2019; Accepted: 30 August 2019; Published: 5 September 2019

\begin{abstract}
Nowadays, increased interest among the scientific community to explore the Calophyllum inophyllum as alternative fuels for diesel engines is observed. This research is about using mixed Calophyllum inophyllum-palm oil biodiesel production and evaluation that biodiesel in a diesel engine. The Calophyllum inophyllum-palm oil methyl ester (CPME) is processed using the following procedure: (1) the crude Calophyllum inophyllum and palm oils are mixed at the same ratio of 50:50 volume \%, (2) degumming, (3) acid-catalysed esterification, (4) purification, and (5) alkaline-catalysed transesterification. The results are indeed encouraging which satisfy the international standards, CPME shows the high heating value $(37.9 \mathrm{MJ} / \mathrm{kg})$ but lower kinematic viscosity $\left(4.50 \mathrm{~mm}^{2} / \mathrm{s}\right)$ due to change the fatty acid methyl ester (FAME) composition compared to Calophyllum inophyllum methyl ester (CIME). The average results show that the blended fuels have higher Brake Specific Fuel Consumption (BSFC) and $\mathrm{NO}_{\mathrm{x}}$ emissions, lower Brake Thermal Efficiency (BTE), along with $\mathrm{CO}$ and $\mathrm{HC}$ emissions than diesel fuel over the entire range of speeds. Among the blends, CPME5 offered better performance compared to other fuels. It can be recommended that the CPME blend has great potential as an alternative fuel because of its excellent characteristics, better performance, and less harmful emission than CIME blends.
\end{abstract}

Keywords: Calophyllum inophyllum biodiesel; palm biodiesel; engine performance; exhaust emissions; alternative fuel; transesterification 


\section{Introduction}

Petroleum derived fuels are the main source of primary energy consumption worldwide. Because of the negative impact and limited reserve of fossil fuels, scientists have focused on the new sources of energy to replace the fossil fuel [1,2]. Renewable energy sources have been proven to create less or zero-emission energy generation and can play an important role to lower fossil fuel consumption [3]. In many countries, different types of renewable energy sources including solar, wind, hydro, geothermal, bioenergy and biofuel has been introduced [4-9]. However, some renewable energy, including wind and solar, are only available for a certain time and period and therefore energy storage is required for these kinds of sources [10]. Due to this problem, researchers attempt to find other types of energy storage material that can be commercialized [11-14]. Therefore, some scientists, especially in developing countries are more interested in the energy sources that can be kept for a long period, such as bioenergy, bioethanol, and biodiesel [15-17]. Biodiesel is one renewable energy source, which can significantly lower emissions due to fossil fuel combustion that create air pollution, global warming, and acid rain [18]. Biodiesel sources include soybean oil, sunflower oil, palm oil and cottonseed oil, Jatropha curcas oil, mahua (Madhuca indica) oil, jojoba (Simmondsia chinensis) oil, tobacco seeds, salmon oil, tamanu (Calophyllum inophyllum) oil, sea mango oil (Cerbera odollam), and microalgae [19-22].

Palm oil has been commonly used in Malaysia and Indonesia as a biodiesel source due to its availability and favorable characteristics [23]. The productive lifetime of palm oil is around 25 years and it has to be replanted after that period [20]. Palm oil can yield methyl ester over $80 \%$. Since 2006, the Indonesia government has paid attention to biodiesel as part of the National Security Act of Indonesia because of world crude oil price fluctuation. It is also supported because Indonesia is the largest crude palm oil (CPO) producer. However, until 2010, the Indonesia government failed to achieve biodiesel blending targets due to the increase in the world crude palm oil price and decrease in the crude oil price. As an impact, the biodiesel price has been not competitive compared to the diesel fuel price [24]. As Ong at al. [19] reported on sensitivity analysis that differences in the price of sources will have considerable impact on the life cycle cost of biodiesel by at least $79 \%$. However, many new policies were introduced in 2014 by the Indonesian government to promote the use of biodiesel. Ong at al. [25] suggested that a financial incentive and subsidy policy should be enforced to make the price of biodiesel competitive to diesel fuel. However, based on a cost-benefit analysis (CBA), this will enhance the net benefit of palm oil plantation and biodiesel producers but will lessen the net welfare for society and the government of Indonesia. Therefore, the policy in the future will focus on reducing costs that improve the net social benefit [24].

Calophyllum inophyllum seed is an inedible oil source, which has a high oil content. Therefore, Calophyllum inophyllum seed is also a potential feedstock for biodiesel fuel [19] in Indonesia and Malaysia due to its abundant availability. This feedstock is a biodiverse plant that was previously known as a medicinal source due to its high antioxidant content [26]. However, Calophyllum inophyllum is grouped into high-acid-number feedstocks that allow biodiesel production to be equipped with special treatments, such as triple-stage transesterification, degumming, and neutralization [6]. In fact, Calophyllum inophyllum biodiesel has a poor oxidation stability because it has about $72.65 \%$ of unsaturated fatty acids that make this fuel unfavourable for long-term storage [27]. Excessive chemical treatment for minimizing total acid number (TAN) in oil refining may lead to a reduction of antioxidant content and oxidation stability [28]. Recently, some experiments reported that the antioxidant addition into biodiesel has improved its oxidation stability.

However, recently many studies have been reported on the fractional replacement of conventional fuel by palm and CIME. There are not many studies that have been reported on the prospect of palm and Calophyllum inophyllum biodiesel mixture. In this work, palm and Calophyllum inophyllum oil were mixed prior to the biodiesel production process and compared their performance with conventional fuel in a diesel engine. This method is believed to be able today reduce the chemical process during the acid value reduction of Calophyllum inophyllum-palm oil compound. Moreover, the objective of this study is also to investigate the engine performance (specifically, the Brake Specific Fuel Consumption 
(BSFC) and Brake Thermal Efficiency (BTE) and exhaust emission characteristics $\mathrm{NO}_{\mathrm{x}}, \mathrm{HC}$, and $\mathrm{CO}$ emissions) of Calophyllum inophyllum-palm biodiesel mixture. It is expected that there is a potential for these blends to be commercialized in Indonesia and Malaysia due to the abundant supply of Calophyllum inophyllum seed oil and palm oil in these countries.

\section{Materials and Methods}

\subsection{Crude Oils}

Crude Calophyllum inophyllum oil and palm oils were purchased from a local store in Kuala Lumpur, Malaysia. The crude Calophyllum inophyllum and palm oils were mixed at 50:50 equal volume \% in order to produce the CPME.

\subsection{Production of CPME}

Firstly, the blend was prepared by mixing $1 \mathrm{~L}$ of the crude oil from each source with $1 \%$ of phosphoric acid $\left(\mathrm{H}_{3} \mathrm{PO}_{4}\right.$, Merck Sdn. Bhd., Kuala Lumput, Malaysia) and $10 \%$ of purified water $(v / v)$ for $30 \mathrm{~min}$. The crude oil mixture was degummed at $60{ }^{\circ} \mathrm{C}$ with an agitation speed of $800 \mathrm{rpm}$. The degumming process is essential to remove impurities and compounds (i.e., resins, proteins, phosphates, carbohydrates, and water residue). Next, acid-catalysed esterification was conducted. The details of the esterification process can be found in Silitonga et al. [29]. Molar ratio and catalyst percentage influence the esterification process of the oils [30]. In this study, it displayed the optimum molar ratio and $\mathrm{H}_{2} \mathrm{SO}_{4}$ catalyst (Merck Sdn. Bhd., Kuala Lumpur, Malaysia) concentration are 1:16.6 and 2.0 vol.\%, respectively, since these parameters result in the highest esterified oil yield and fastest reaction time. According to [31], the presence of excess water can increase the formation of peroxides and increase the free fatty acid content of esterified oils. Thus, purification is crucial to remove excess water, which can be done by evaporation using a rotary evaporator, followed by the separation process with a separating funnel [32,33].

For this experiment, the esterified Calophyllum inophyllum-palm oil was purified by stirring the oil in a rotary evaporator (RV10 DIGITAL V IKA, Germany) at $60{ }^{\circ} \mathrm{C}$ with a stirring speed of $100 \mathrm{rpm}$ for $30 \mathrm{~min}$. The maximum pressure of the rotary evaporator was $7.2 \mathrm{MPa}$ (72 bars). Following this, the esterified Calophyllum inophyllum-palm oil was poured into a separating funnel for the settling and left for $18 \mathrm{~h}$. Karmakar et al. [21] also found that the high temperature of the purification process results in hydrolysis of the triglycerides, which in turn, removes water from the esterified oil.

Next, transesterification was done by mixing the esterified oils with $50 \%$ of methanol and 0.5 volume \% of sodium hydroxide (KOH, Merck Sdn. Bhd., Kuala Lumpur, Malaysia) catalyst. The reaction mixture was stirred continuously in a jacketed reactor for $90 \mathrm{~min}$ maintaining the temperature at $60^{\circ} \mathrm{C}$. On the completion of the transesterification, the mixture was left for $4-6 \mathrm{~h}$ in a funnel. There are two distinct layers of liquid formed in the funnel where biodiesel was in the top and glycerol at the bottom. The glycerol was drained out from the funnel and biodiesel was washed by using sanitized water for a number of times in order to further remove impurities. The similar purification process was maintained both for the esterification and transesterification process.

\subsection{Production of Methyl Ester}

The CIME and palm oil methyl ester (POME) were prepared in the same manner. The crude Calophyllum inophyllum and palm oils were first degummed to remove impurities. The degummed oils were then esterified under the following process conditions: (1) reaction temperature; $60^{\circ} \mathrm{C}$, (2) stirring speed; $800 \mathrm{rpm}$, (3) reaction time; $60 \mathrm{~min}$, (4) oil-to-methanol molar ratio; 1:16.6, and (5) $\mathrm{H}_{2} \mathrm{SO}_{4}$ catalyst concentration; $1.0 \mathrm{vol} . \%$. The esterified oils were then purified to remove extraneous water present in the oils. Next, the purified Calophyllum inophyllum and palm oils were transesterified under the following process conditions: (1) reaction temperature; $60^{\circ} \mathrm{C}$, (2) stirring speed; $800 \mathrm{rpm}$, (3) reaction time; $90 \mathrm{~min}$, (4) oil-to-methanol ratio; 1:8, and (5) catalyst- $\mathrm{KOH}$ with concentration; 
0.5 vol. $\%$. Likewise, the reaction mixtures were left to settle in separating funnels for $4-6 \mathrm{~h}$ after the transesterification process. In the final step, the CIME and POME were cleaned using sanitized water several times.

\subsection{Characteristics of the CPME}

The characteristics (i.e., density, kinematic viscosity (KV), flash point (FP), acid value(AV), high heating value (HHV), FAME content, and oxidation stability of the CPME and its blends were examined and compared to diesel, POME, CIME, as well as their blends. The FAME content was determined by employing a gas chromatograph-mass spectrometer (Model: GCMS-QP2010 Ultra, Shimadzu, Japan) fitted with a low-bleed GC-MS column (Model: RTX-5MS, RESTEK, Tokyo, Japan) details operating condition can be found elsewhere [34]. The temperature of the flame ionization detector and split injector was $300{ }^{\circ} \mathrm{C}$. The biodiesels chemical and physical properties are collected from literature as a comparison.

The FAME content in per cent (\%) determined by the following Equation:

$$
\mathrm{FAME}=\frac{\left(\sum A\right)-A_{E I}}{A_{E I}} \times \frac{C_{E I} \times V_{E I}}{m} \times 100
$$

Here, $\sum A$ is the summation of the peak areas of FAME, $A_{E I}$ is the methyl heptadecanoate peak area, which is the internal standard, $C_{E I}$ is the methyl heptadecanoate solution concentration in heptane $(\mathrm{mg} / \mathrm{mL}), V_{E I}$ is the methyl heptadecanoate solution volume $(\mathrm{mL})$ and $m$ is the methyl ester mass $(\mathrm{mg})$.

The percentage (\%) of the methyl ester yield can be calculated by the following Equation:

$$
\text { Methyl ester yield }=\frac{F A M E \times B_{\text {cpme }}}{O_{\text {cipo }}} \times 100
$$

The FAME is the fatty acid methyl ester content $(\%), B_{c p}$ is the Calophyllum inophyllum-palm oil methyl ester weight $(\mathrm{g})$ and $O_{s o}$ is the weight of the Calophyllum inophyllum-palm mixed oil (g).

\subsection{Experimental Set-Up}

Engine tests were done to study the engine performance and the characteristics of exhaust emission for CPME blends and CIME blends and the data collected compared to diesel fuel. These fuel blends were prepared in this study: (1) CPME5, (2) CPME10, (3) CIME5, and (4) CIME10. In this study, the performance parameters BSFC and BTE whereas the exhaust gases parameter $\mathrm{NO}_{x}, \mathrm{HC}$, and $\mathrm{CO}$ were measured. A single-cylinder diesel engine (Yanmar YX2500CX-A 170F, Osaka, Japan) was used to investigate the performance that set in full throttle. The engine speed varied from 1400 to $2800 \mathrm{rpm}$. A BOSCH BEA 350 gas analyser was used in order to measure the emissions. The detail of the engine test-bed and emission analyser is given in Table 1.

Table 1. Diesel engine technical specifications.

\begin{tabular}{cc}
\hline Brand & Yanmar \\
Model & 2500CX-A 170 F \\
Type & 1-cylinder, DI \\
Displacement (cc) & 211 \\
Speed (rpm) & 3000 \\
Maximum output(HP) & 4.2 \\
Cont. output (HP) & 3.8 \\
Governor System & Centrifugal weight system \\
Starting system & Recoil or electric \\
Lube oil capacity(L) & 0.75 \\
Fuel tank capacity(L) & 12.5 \\
Operational capacity (hrs.) & 14 \\
\hline
\end{tabular}




\subsection{Uncertainties of the Experimental}

Generally, the uncertainties of the experiment happened due to several reasons, namely: (1) instruments type and condition, (2) instruments calibration, (3) environmental conditions, and (4) procedure of experimental. To make sure the accuracy of the data between the limit, therefore the accuracy of the experimental data should be verified. Consequently, the uncertainties percentage of selected variables, namely BSFC, $\mathrm{BTE}, \mathrm{CO}, \mathrm{NO}_{\mathrm{x}}$, and $\mathrm{HC}$ were investigated according to the instrument's percentage uncertainties employed in the experiments. The speed accuracy, fuel consumption flowrate and time, which were $\pm 10 \mathrm{rpm}, \pm 1 \%$, and $\pm 0.1 \mathrm{~s}$, respectively. The BSFC uncertainty was investigated by the uncertainty linearized approximation method. The details of $\%$ of uncertainties are given in Table 2.

Table 2. The percentage of uncertainties.

\begin{tabular}{|c|c|c|c|c|}
\hline $\begin{array}{c}\text { Measured } \\
\text { Quantity }\end{array}$ & $\begin{array}{l}\text { Measurement } \\
\text { Range }\end{array}$ & Accuracy & Type of Instrument & $\begin{array}{c}\text { Percentage } \\
\text { Uncertainty }(\%)\end{array}$ \\
\hline Load & $\pm 8 \mathrm{Nm}$ & $\pm 0.1 \mathrm{Nm}$ & Strain gauge type load cell & \pm 1.27 \\
\hline Speed & $1400-2800 \mathrm{rpm}$ & $\pm 1 \mathrm{rpm}$ & Magnetic pickup type speed sensor & \pm 0.1 \\
\hline Time & - & $\pm 0.1 \mathrm{~s}$ & 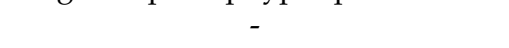 & \pm 0.2 \\
\hline $\begin{array}{l}\text { Fuel flow } \\
\text { measurement }\end{array}$ & $1-25 \mathrm{~L} / \mathrm{h}$ & $\pm 0.1 \mathrm{~L} / \mathrm{h}$ & $\begin{array}{l}\text { Positive displacement gear wheel } \\
\text { flow meter }\end{array}$ & \pm 1.53 \\
\hline $\mathrm{CO}$ & $0 \%-10 \%$ by vol. & $\pm 0.001 \%$ & Non-dispersive infrared gas sensor & \pm 1.13 \\
\hline $\mathrm{HC}$ & $0-9,999$ ppm & $\pm 1 \mathrm{ppm}$ & Heated flame ionization detector & \pm 1.4 \\
\hline $\mathrm{NO}_{x}$ & $0-5,000$ ppm vol & \pm 1 ppm vol & Electrochemical gas sensor & \pm 1.1 \\
\hline BSFC & - & $\pm 0.1 \mathrm{~L} / \mathrm{kWh}$ & - & \pm 1.5 \\
\hline BTE & - & $\pm 0.2 \%$ & - & \pm 1.5 \\
\hline
\end{tabular}

\section{Results and Discussion}

\subsection{Physicochemical Properties}

The properties for POME, CIME, CPME, and their blends are given in Table 3. It is seen that the density of the CPME $\left(880 \mathrm{~kg} / \mathrm{m}^{3}\right)$ is lower than that for CIME $\left(884 \mathrm{~kg} / \mathrm{m}^{3}\right)$. The KV of the CPME was found lower than that for CIME and similar to that for POME $\left(4.4 \mathrm{~mm}^{2} / \mathrm{s}\right)$. In general, the KVs for CPME, CIME, and POME are inline with ASTM D6751 limit. The FP of CPME is $160^{\circ} \mathrm{C}$, which is above the limit of ASTM D6751 standard. The higher FP is important as it reduces the fire hazard risk, which is the main concern on fuels to handle, transport, and store [35]. However, the HHV of the CPME (37.9 MJ/kg) is found to be greater than CIME and POME (37.3 and 36.4 MJ/kg, respectively). 
Table 3. Comparative physicochemical properties of the fuel sample used.

\begin{tabular}{|c|c|c|c|c|c|c|c|c|c|c|c|c|c|c|c|}
\hline \multirow[b]{2}{*}{ Property } & \multicolumn{2}{|c|}{ Limit } & \multirow[b]{2}{*}{ Diesel } & \multicolumn{6}{|c|}{ Biodiesel } & \multicolumn{6}{|c|}{ Biodiesel Blends } \\
\hline & $\begin{array}{l}\text { ASTM } \\
\text { D6751 }\end{array}$ & $\begin{array}{c}\text { EN } \\
14214\end{array}$ & & POME & CIME & CPME & $\begin{array}{l}\text { CSO + WSO } \\
\text { (Fadhil, } \\
\text { 2017) }\end{array}$ & $\begin{array}{l}\text { JCME } \\
\text { (Dharma, } \\
\text { 2016) }\end{array}$ & $\begin{array}{l}\text { NSME + CPME } \\
\text { (Yunus khan, } \\
\text { 2014) }\end{array}$ & CIME5 & CIME10 & CPME5 & CPME10 & $\begin{array}{c}\text { JCB10 (Dharma, } \\
\text { 2016) }\end{array}$ & $\begin{array}{c}\text { NSCPB } \\
\text { (Yunus khan, } \\
\text { 2014) }\end{array}$ \\
\hline $\begin{array}{c}\text { Density at } \\
15^{\circ} \mathrm{C}\left(\mathrm{kg} / \mathrm{m}^{3}\right)\end{array}$ & 880.0 & $860.0-900.0$ & 846.3 & 874.0 & 884.0 & 880.0 & 898.9 & 831.2 & 884.8 & 852.0 & 854.0 & 853.0 & 854.0 & 854 & 854.0 \\
\hline $\begin{array}{c}\mathrm{KV} \text { at } 40^{\circ} \mathrm{C} \\
\left(\mathrm{mm}^{2} / \mathrm{s}\right)\end{array}$ & $1.90-6.00$ & $3.50-5.00$ & 2.98 & 4.40 & 4.80 & 4.50 & 3.61 & 3.95 & 4.44 & 3.76 & 4.00 & 3.82 & 4.00 & 3.55 & 3.70 \\
\hline $\mathrm{FP}\left({ }^{\circ} \mathrm{C}\right)$ & $>130.0$ & $\begin{array}{l}\text { Min. } \\
101.0\end{array}$ & 80.0 & 246.5 & 179.0 & 160.0 & 246.5 & 84 & 186.5 & 86.0 & 88.0 & 79.9 & 82.0 & 76.5 & 87.5 \\
\hline $\mathrm{HHV}(\mathrm{MJ} / \mathrm{kg})$ & - & 35.0 & 45.3 & 36.4 & 37.3 & 37.9 & 36.4 & 40.88 & 39.94 & 43.1 & 42.9 & 44.1 & 43.9 & 42.76 & 44.2 \\
\hline $\begin{array}{l}\mathrm{AV}(\mathrm{mg} \\
\mathrm{KOH} / \mathrm{g})\end{array}$ & $<0.50$ & $<0.50$ & - & 0.1 & 0.5 & 0.4 & 0.1 & 0.06 & 0.14 & 0.1 & 0.5 & 0.4 & 0.1 & 0.36 & 0.1 \\
\hline $\begin{array}{c}\text { Water } \\
\text { content }(\% \mathrm{v})\end{array}$ & $\begin{array}{l}\text { Max. } \\
0.05\end{array}$ & - & - & 0.025 & 0.015 & 0.018 & - & - & - & 0.015 & 0.0015 & 0.002 & 0.0018 & - & - \\
\hline
\end{tabular}




\subsection{Fatty Acid Methyl Ester (FAME) Composition}

The FAME compositions of the CIME, POME, and CPME are summarized in Table 4. In general, all of these biodiesels have high palmitic acid content. However, the POME has a higher percentage of oleic acid, whereas the CPME has a higher percentage of antioxidants, such as methyl palmitic acid (C16:0), stearic acid (C18:0), linoleic acid $\left(\mathrm{C}_{18} \mathrm{H}_{36} \mathrm{O}_{2}\right)$, and 9-Octadecene,1-methoxy-, $(\mathrm{E})\left(\mathrm{C}_{19} \mathrm{H}_{38} \mathrm{O}\right)$ [34]. Moreover, the CPME has a high oleic acid percentage (C18:1), with a value of $52.94 \mathrm{wt} . \%$, which also serves as a lubricant.

Table 4. Fatty Acid Methyl Ester (FAME) composition of Calophyllym inophyllum Methyl ester, CIME, Palm Oil Methyl Ester (POME), and Ceiba Pentandra Methyl ester (CPME).

\begin{tabular}{cccc}
\hline Fatty Acid & CIME (wt.\%) & POME (wt.\%) & CPME (wt.\%) \\
\hline Lauric acid & 0.10 & 0.10 & 0.10 \\
Myristic acid & 0.75 & 1.52 & 0.93 \\
Palmitic acid & 16.85 & 25.10 & 28.22 \\
Palmitoleic acid & 0.70 & 0.67 & 0.75 \\
Stearic acid & 15.57 & 22.46 & 31.99 \\
Oleic acid & 41.5 & 56.29 & 52.94 \\
Linoleic acid & 15.10 & 6.85 & 16.35 \\
Linolenic acid & 0.13 & 7.61 & 5.32 \\
Arachidic acid & 0.10 & 0.10 & 0.10 \\
\hline
\end{tabular}

\subsection{Brake Specific Fuel Consumption (BSFC)}

Figure 1 shows the BSFC for diesel, CPME and CIME biodiesel blends at various engine speeds. It can be observed that all the blended fuel have higher BSFC compared to the diesel fuel except CPME5 blend. On average, biodiesel blended fuels have $16 \%-21 \%$ higher BSFC than diesel fuel. This finding is consistent with the literature [36-38]. Öztürk et al. [38] investigated the mixture of canola oil-hazelnut soap stock biodiesel-diesel and they found that the BSFC of blend fuel is more than the diesel fuel. The combined effects of the density, KV and HHV of the fuel caused that result [39]. During the suction stroke, biodiesel is injected on a volume basis; thus more fuels are fed inside the cylinder [40]. Consequently, more fuel is needed in order to achieve the same power because the HHV of biodiesel is lower than diesel. Among the blends, the average BSFC was highest for CIME10 blend ( $2.58 \mathrm{Ltr} / \mathrm{kWhr}$ ) and lowest for CIME5 (2.21 Ltr/kWhr), which can be attributed by the HHV of the CIME10 blends. According to the data presented in Table 3, fuel sample CIME10 have a slightly higher heating value (43.9 MJ/kg) compared with CPME5 (43.1 MJ/kg).

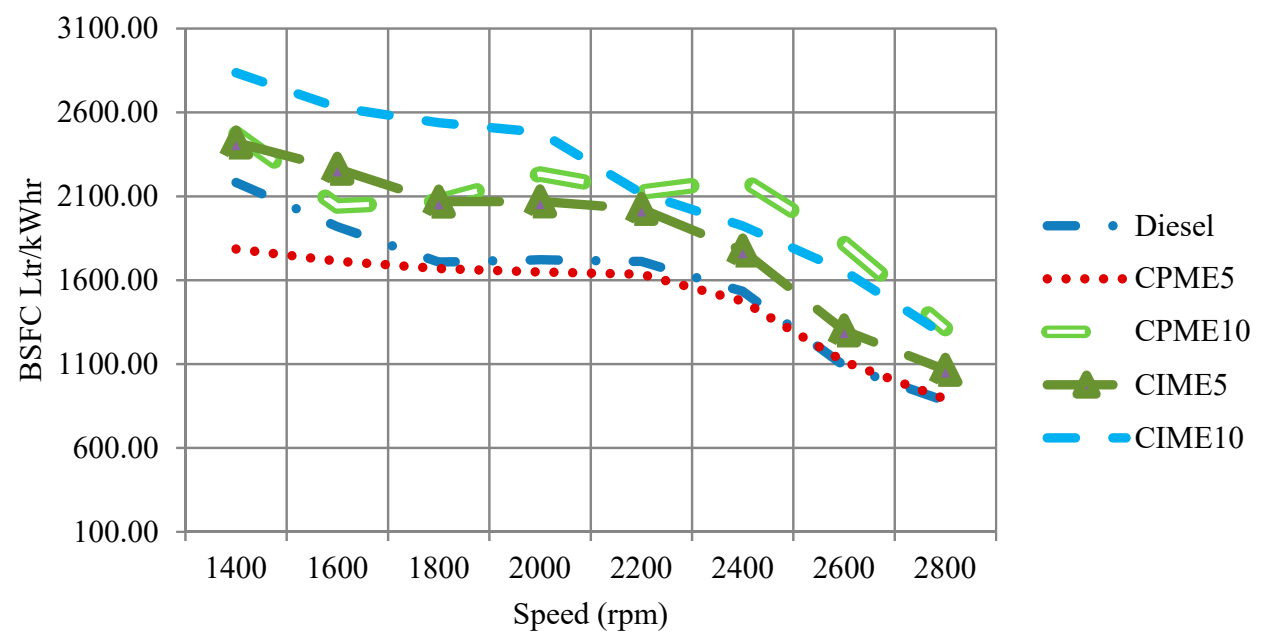

Figure 1. Changes in Brake Specific Fuel Consumption (BSFC) of diesel, CPME, and CIME blends with speeds. 


\subsection{Brake Thermal Efficiency (BTE)}

Figure 2 shows the BTE for all fuel samples at different speeds of the engine. It is seen that the BTEs of all fuel samples used in this study increases with the speed and maximum BTE was found for diesel fuel compared to blended fuels. This can be explained by the higher heating value and lower BSFC of diesel fuel [41]. Diesel fuel showed maximum BTE followed by the CPME5, CIME5, CPME10, and CIME10 fuels. On average blended fuel lowers $1.25 \%-22 \%$ BTE compared to diesel fuel. The lower viscosity and higher heating value of diesel fuel, which improves the fuel atomization; thus increased the BTEs. The data obtained from the experiment are similar to the results presented by Sharma et al. [42]. They reported that the mixed Jatropha and Cottonseed blend produce lower BTE than diesel fuel. The reason was explained by the poor spray formation, higher viscosity, and poor ignition quality.

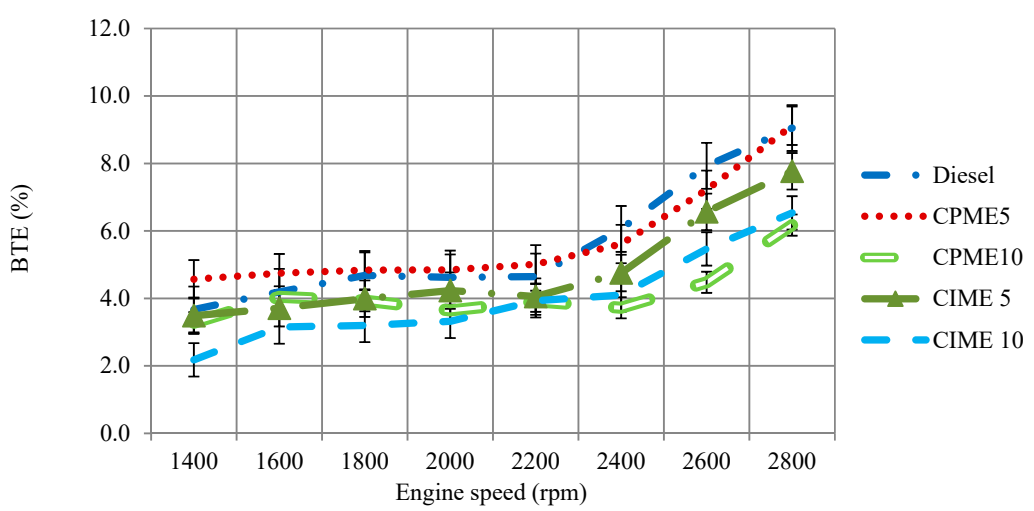

Figure 2. Changes in Brake Thermal Efficiency (BTE) of diesel, CPME, and CIME blends with speeds.

\subsection{Nitrogen Oxide Emissions $\left(N O_{x}\right)$ Emission}

The nitrogen oxides emissions in exhaust consist of nitric oxide $(\mathrm{NO})$ and nitrogen dioxide $\left(\mathrm{NO}_{2}\right)$. Figure 3 shows the $\mathrm{NO}_{x}$ emissions for diesel, and the CPME and CIME biodiesel blends at various engine speeds. It is evident that the $\mathrm{NO}_{x}$ emissions increase with an increase in engine speed. It is clear that biodiesel blended fuels give more $\mathrm{NO}_{\mathrm{x}}$ emissions compared to diesel fuel. A similar report was found in the literature [43] for B7 and B100. The average $\mathrm{NO}_{\mathrm{x}}$ for diesel fuel was found to be $112 \mathrm{ppm}$, which is $1.5 \%-29 \%$ higher than the blended fuels. This can be explained by the lean air/fuel ratio because biodiesel fuel has more inherent oxygen than diesel fuel. It has been reported that oxygenated fuel blends cause higher $\mathrm{NO}_{x}$ emissions [36]. Also, the higher $\mathrm{KV}$ of the biodiesel fuel leads to bigger droplets and shorter ignition delays, which affects the $\mathrm{NO}_{\mathrm{x}}$ emission [44]. In addition, the unsaturated fatty acid content of biodiesels leads to fuels higher adiabatic flame temperature than diesel fuel, which causes higher $\mathrm{NO}_{x}$ emission [43].

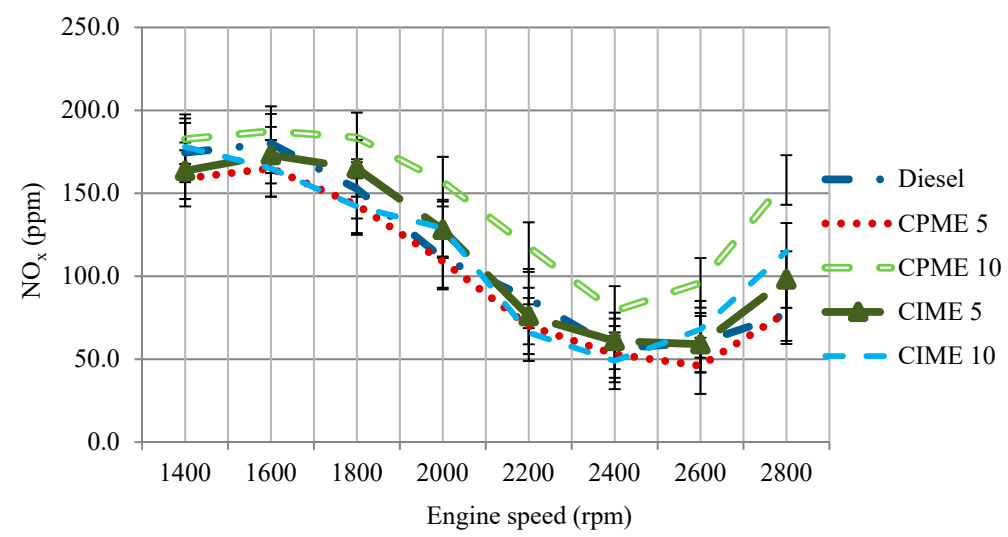

Figure 3. Changes in Nitrogen Oxide ( $\mathrm{NO}_{\mathrm{x}}$ ) emissions of diesel, CPME, and CIME blends with speeds. 


\subsection{Carbon Monoxide (CO) Emissions}

Figure 4 shows the $\mathrm{CO}$ emissions of all fuel samples at various engine speeds. The results indicate that the $\mathrm{CO}$ emissions are generally fewer for the biodiesel blends than the diesel fuel. Among the fuel samples, biodiesel fuel lowers 5\% to $15 \% \mathrm{CO}$ emission on average compared to the diesel fuel. The reason is described by the higher oxygen content of the biodiesels, which results in cleaner, better combustion $[45,46]$. CO is formed due to the incomplete combustion of the fuel due to insufficient oxygen or low gas temperature. As mentioned earlier, biodiesel fuel has a $12 \%$ higher oxygen content than diesel fuel, which accepts more carbon molecules to be burnt completely [36].

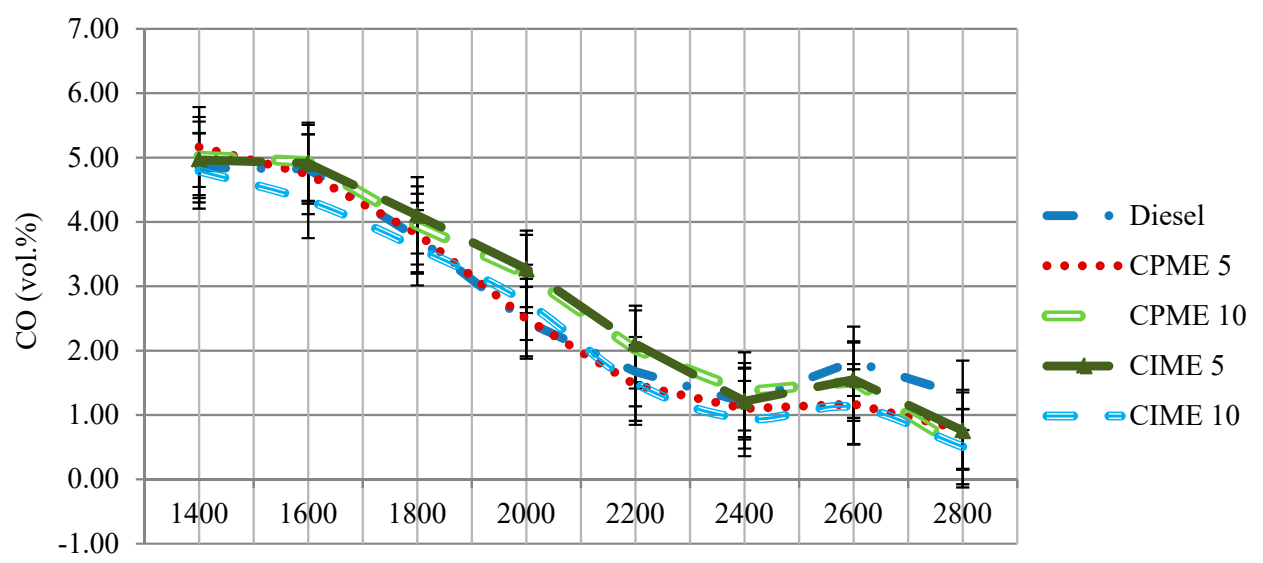

Engine speed (rpm)

Figure 4. Changes in Carbon Monoxide (CO) emissions of diesel, CPME, and CIME blends with speeds.

\subsection{Hydrocarbon (HC) Emissions}

The comparison of emission among the fuel samples related to $\mathrm{HC}$ is presented in Figure 5. It was found that average HC emissions of blends were less than diesel. It is obvious that biodiesel blended fuel lowers $\mathrm{HC}$ emissions by $13 \%-22 \%$ than diesel fuel. The HC emissions can be reduced by the combustion quality improvement in biodiesel diesel blends due to the existence of excess oxygen atoms in biodiesel [47]. Similar results were reported by Mofijur et al. [37]. They explained that lower hydrocarbon emissions of moringa biodiesel-diesel occur because of higher oxygen contents of biodiesel fuel than diesel fuel. Also from the graph, it is seen that with increasing engine speeds, the HC emission decreases. Kegl et al. [48] presented similar results that both biodiesel and diesel fuels emit higher HC emissions when engines run at lower speeds.

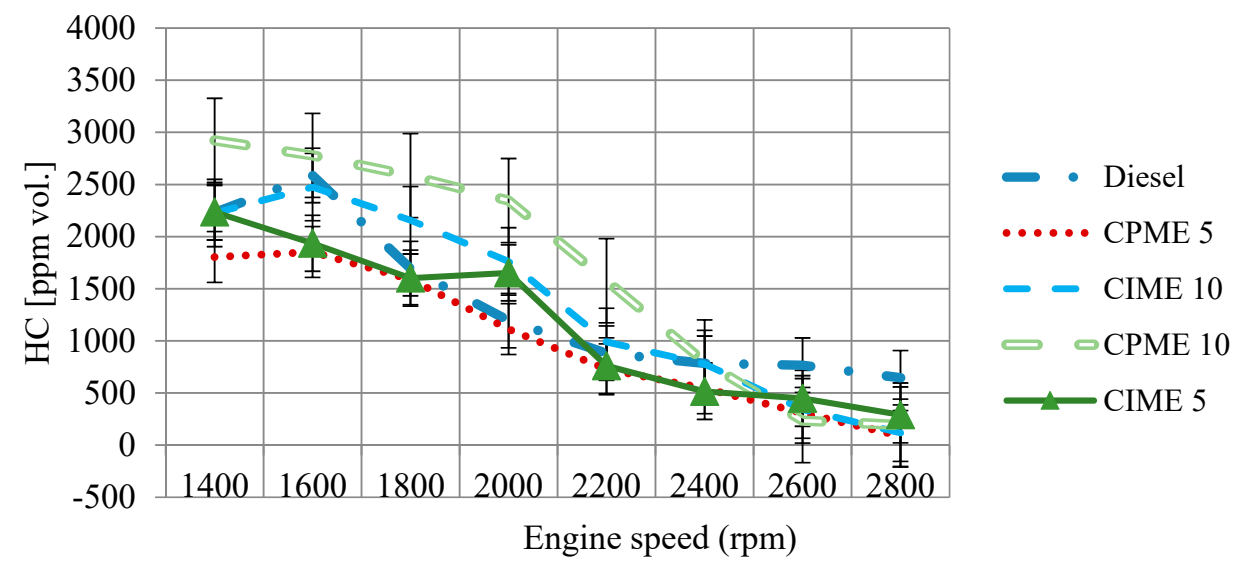

Figure 5. Changes in Hydrocarbon (HC) emissions of diesel, CPME, and CIME blends with speeds. 


\section{Conclusions}

In this study, CPME is produced by a systematic procedure that started from crude oil mixing and ended by the transesterification process. Based on the findings, the following conclusions can be made:

1. The physicochemical properties of CPME meet ASTM D6751 and EN 14214 standards

2. The blended fuel results in lower BTE and higher BSFC compared the diesel fuel because of its higher KV, density, and lower HHV.

3. The use of blended fuel as a partial replacement of diesel significantly decreased the $\mathrm{CO}$ and HC emission, which is likely due to the fact that this blend promotes complete combustion whereas there is a slight increase in $\mathrm{NO}_{x}$ emissions due to higher oxygen contents.

4. Among the blends, CPME5 showed a better performance compared to the other blends.

Finally, it can be concluded the CPME blend has potential as a diesel engine alternative fuel to lower the harmful emission.

Author Contributions: Conceptualization, Methodology, results and formal analysis were initiated and wrote by N.D., A.S.S. and H.C.O.; T.M.I.M., A.H.S. (Abd Halim Shamsuddin) and C.W.T. contributed to supervision. A.H.S. (Abdi Hanra Sebayang), M.M. contributed to the Mathematical derivation and results analysis; C.-T.W. and J.-H.J. checked and improved the manuscript. All authors read and approved the final manuscript.

Funding: This research is funded by the Centre for Advanced Modeling and Geospatial Information Systems (CAMGIS), UTS under Grants 321740.2232397 and AAIBE Chair of Renewable grant no: 201801 KETTHA. The authors would like to acknowledge the University of Malaya, Kuala Lumpur for the financial support under SATU joint research scheme (ST010-2018), the Direktorat Jenderal Penguatan Riset dan Pengembangan Kementerian Riset, Teknologi dan Pendidikan Tinggi Republik Indonesia, (Grant no. 147/SP2H/LT/ DRPM/2019) and Politeknik Negeri Medan, Medan, Indonesia.

Acknowledgments: The authors would like to acknowledge the University of Technology Sydney, Australia for supporting this research.

Conflicts of Interest: The authors declare no conflict of interest.

\section{Abbreviations}

CIME Calophyllum inophyllum methyl ester

CIME5 5\% Calophyllum inophyllum methyl ester $+95 \%$ of diesel

CIME10 $10 \%$ Calophyllum inophyllum methyl ester $+90 \%$ of diesel

CPME Calophyllum inophyllum-palm oil methyl ester

CPME5 5\% Calophyllum inophyllum-palm oil methyl ester $+95 \%$ of diesel

CPME10 10\% Calophyllum inophyllum-palm oil methyl ester $+90 \%$ of diesel

BSFC Brake Specific Fuel Consumption

$\mathrm{CO} \quad$ Carbon monoxides

$\mathrm{HC} \quad$ Hydrocarbon

$\mathrm{NO}_{\mathrm{x}} \quad$ Nitrogen oxides

\section{References}

1. Norhasyima, R.S.; Mahlia, T.M.I. Advances in $\mathrm{CO}_{2}$ utilization technology: A patent landscape review. J. CO2 Util. 2018, 26, 323-335. [CrossRef]

2. Mofijur, M.; Masjuki, H.H.; Kalam, M.A.; Hazrat, M.A.; Liaquat, A.M.; Shahabuddin, M.; Varman, M. Prospects of biodiesel from Jatropha in Malaysia. Renew. Sustain. Energy Rev. 2012, 16, 5007-5020. [CrossRef]

3. Anwar, M.; Rasul, M.G.; Ashwath, N.; Rahman, M.M. Optimisation of second-generation biodiesel production from Australian native stone fruit oil using response surface method. Energies 2018, 11, 2566. [CrossRef]

4. Ismail, M.S.; Moghavvemi, M.; Mahlia, T.M.I. Techno-economic analysis of an optimized photovoltaic and diesel generator hybrid power system for remote houses in a tropical climate. Energy Convers. Manag. 2013, 69, 163-173. [CrossRef] 
5. Milano, J.; Ong, H.C.; Masjuki, H.H.; Silitonga, A.S.; Chen, W.-H.; Kusumo, F.; Dharma, S.; Sebayang, A.H. Optimization of biodiesel production by microwave irradiation-assisted transesterification for waste cooking oil-Calophyllum inophyllum oil via response surface methodology. Energy Convers. Manag. 2018, 158, 400-415. [CrossRef]

6. Ong, H.C.; Masjuki, H.H.; Mahlia, T.M.I.; Silitonga, A.S.; Chong, W.T.; Leong, K.Y. Optimization of biodiesel production and engine performance from high free fatty acid Calophyllum inophyllum oil in CI diesel engine. Energy Convers. Manag. 2014, 81, 30-40. [CrossRef]

7. Silitonga, A.S.; Masjuki, H.H.; Mahlia, T.M.I.; Ong, H.C.; Chong, W.T. Experimental study on performance and exhaust emissions of a diesel engine fuelled with Ceiba pentandra biodiesel blends. Energy Convers. Manag. 2013, 76, 828-836.

8. Silitonga, A.S.; Masjuki, H.H.; Ong, H.C.; Sebayang, A.H.; Dharma, S.; Kusumo, F.; Siswantoro, J.; Milano, J.; Daud, K.; Mahlia, T.M.I.; et al. Evaluation of the engine performance and exhaust emissions of biodiesel-bioethanol-diesel blends using kernel-based extreme learning machine. Energy 2018, 159, 1075-1087. [CrossRef]

9. Uddin, M.; Techato, K.; Taweekun, J.; Rahman, M.; Rasul, M.; Mahilia, T.; Ashrafur, S. An overview of recent developments in biomass pyrolysis technologies. Energies 2018, 11, 3115.

10. Mofijur, M.; Mahlia, T.M.I.; Silitonga, A.S.; Ong, H.C.; Silakhori, M.; Hasan, M.H.; Putra, N.; Rahman, S.M.A. Phase change materials (PCM) for solar energy usages and storage: An overview. Energies 2019, 12, 3167. [CrossRef]

11. Aricò, A.S.; Bruce, P.; Scrosati, B.; Tarascon, J.M.; van Schalkwijk, W. Nanostructured materials for advanced energy conversion and storage devices. Nat. Mater. 2005, 4, 366-377. [CrossRef] [PubMed]

12. Liu, C.; Li, F.; Ma, L.P.; Cheng, H.M. Advanced materials for energy storage. Adv. Mater. 2010, 22, E28-E62. [CrossRef] [PubMed]

13. Amin, M.; Putra, N.; Kosasih, E.A.; Prawiro, E.; Luanto, R.A.; Mahlia, T.M.I. Thermal properties of beeswax/graphene phase change material as energy storage for building applications. Appl. Therm. Eng. 2017, 112, 273-280. [CrossRef]

14. Mehrali, M.; Latibari, S.T.; Mehrali, M.; Mahlia, T.M.I.; Metselaar, H.S.C.; Naghavi, M.S.; Sadeghinezhad, E.; Akhiani, A.R. Preparation and characterization of palmitic acid/graphene nanoplatelets composite with remarkable thermal conductivity as a novel shape-stabilized phase change material. Appl. Therm. Eng. 2013, 61, 633-640. [CrossRef]

15. Colombo, G.; Ocampo-Duque, W.; Rinaldi, F. Challenges in bioenergy production from sugarcane mills in developing countries: A case study. Energies 2014, 7, 5874-5898. [CrossRef]

16. Chia, S.R.; Ong, H.C.; Chew, K.W.; Show, P.L.; Phang, S.-M.; Ling, T.C.; Nagarajan, D.; Lee, D.-J.; Chang, J.-S. Sustainable approaches for algae utilisation in bioenergy production. Renew. Energy 2018, 129, 838-852. [CrossRef]

17. Dharma, S.; Masjuki,H.H.; Ong,H.C.; Sebayang, A.H.; Silitonga, A.S.; Kusumo, F.; Mahlia, T.M.I. Optimization of biodiesel production process for mixed Jatropha curcas-Ceiba pentandra biodiesel using response surface methodology. Energy Convers. Manag. 2016, 115, 178-190. [CrossRef]t

18. Silitonga, A.S.; Mahlia, T.M.I.; Kusumo, F.; Dharma, S.; Sebayang, A.H.; Sembiring, R.W.; Shamsuddin, A.H. Intensification of Reutealis trisperma biodiesel production using infrared radiation: Simulation, optimisation and validation. Renew. Energy 2019, 133, 520-527. [CrossRef]

19. Ayodele, O.O.; Dawodu, F.A. Production of biodiesel from Calophyllum inophyllum oil using a cellulose-derived catalyst. Biomass Bioenergy 2014, 70, 239-248. [CrossRef]

20. Kusumo, F.; Silitonga, A.S.; Masjuki, H.H.; Ong, H.C.; Siswantoro, J.; Mahlia, T.M.I. Optimization of transesterification process for Ceiba pentandra oil: A comparative study between kernel-based extreme learning machine and artificial neural networks. Energy 2017, 134, 24-34. [CrossRef]

21. Kusumo, F.; Silitonga, A.S.; Ong, H.C.; Masjuki, H.H.; Mahlia, T.M.I. A comparative study of ultrasound and infrared transesterification of Sterculia foetida oil for biodiesel production. Energy Sour. Part A Recovery Util. Environ. Eff. 2017, 39, 1339-1346. [CrossRef]

22. Goh, B.H.H.; Ong, H.C.; Cheah, M.Y.; Chen, W.-H.; Yu, K.L.; Mahlia, T.M.I. Sustainability of direct biodiesel synthesis from microalgae biomass: A critical review. Renew. Sustain. Energy Rev. 2019, 107, 59-74. [CrossRef] 
23. Hayyan, A.; Mjalli, F.S.; Hashim, M.A.; Hayyan, M.; AlNashef, I.M.; Al-Wahaibi, T.; Al-Wahaib, Y.M. A Solid organic acid catalyst for the pretreatment of low-grade crude palm oil and biodiesel production. Int. J. Green Energy 2014, 11, 129-140. [CrossRef]

24. Halim, I.F. Cost-Benefit Analysis of Biodiesel Related Policies: The Assessment of Applicability. Master's Thesis, Delft University of Technology, Delft, The Netherland, 2015.

25. Ong, H.C.; Masjuki, H.H.; Mahlia, T.M.I.; Silitonga, A.S.; Chong, W.T.; Yusaf, T. Engine performance and emissions using Jatropha curcas, Ceiba pentandra and Calophyllum inophyllum biodiesel in a CI diesel engine. Energy 2014, 69, 427-445.

26. Prasad, J.; Shrivastava, A.; Khanna, A.K.; Bhatia, G.; Awasthi, S.K.; Narender, T. Antidyslipidemic and antioxidant activity of the constituents isolated from the leaves of Calophyllum inophyllum. Phytomedicine 2012, 19, 1245-1249. [CrossRef] [PubMed]

27. Sahoo, P.K.; Das, L.M.; Babu, M.K.G.; Naik, S.N. Biodiesel development from high acid value polanga seed oil and performance evaluation in a CI engine. Fuel 2007, 86, 448-454. [CrossRef]

28. Pullen, J.; Saeed, K. Experimental study of the factors affecting the oxidation stability of biodiesel FAME fuels. Fuel Process. Technol. 2014, 125, 223-235. [CrossRef]

29. Silitonga, A.S.; Masjuki, H.H.; Ong, H.C.; Yusaf, T.; Kusumo, F.; Mahlia, T.M.I. Synthesis and optimization of Hevea brasiliensis and Ricinus communis as feedstock for biodiesel production: A comparative study. Ind. Crops Prod. 2016, 85, 274-286. [CrossRef]

30. Kombe, G.G. Re-esterification of high free fatty acid oils for biodiesel production. Biofuels 2015, 6, 31-36. [CrossRef]

31. Yaakob, Z.; Narayanan, B.N.; Padikkaparambil, S.; Unni, K.S.; Akbar, P.M. A review on the oxidation stability of biodiesel. Renew. Sustain. Energy Rev. 2014, 35, 136-153. [CrossRef]

32. Dinkov, R.; Hristov, G.; Stratiev, D.; Boynova Aldayri, V. Effect of commercially available antioxidants over biodiesel/diesel blends stability. Fuel 2009, 88, 732-737. [CrossRef]

33. Kirk-Othmer. Esterification. Kirk-Othmer Encyclopedia of Chemical Technology, 4th ed.; John Wiley \& Sons, Inc.: Hoboken, NJ, USA, 2004.

34. Kumar, N.R.; Reddy, J.S.; Gopikrishna, G.; Solomon, K.A. GC-MS determination of bioactive constituent of cycas beddomei cones. Int. J. Pharm. Bio Sci. 2012, 3, 344-350.

35. Nantha Gopal, K.; Thundil Karupparaj, R. Effect of Pongamia biodiesel on emission and combustion characteristics of DI compression ignition engine. Ain Shams Eng. J. 2015, 6, 297-305. [CrossRef]

36. Mofijur, M.; Masjuki, H.H.; Kalam, M.A.; Atabani, A.E. Evaluation of biodiesel blending, engine performance and emissions characteristics of Jatropha curcas methyl ester: Malaysian perspective. Energy 2013, 55, 879-887. [CrossRef]

37. Mofijur, M.; Masjuki, H.H.; Kalam, M.A.; Atabani, A.E.; Fattah, I.M.R.; Mobarak, H.M. Comparative evaluation of performance and emission characteristics of Moringa oleifera and Palm oil based biodiesel in a diesel engine. Ind. Crops Prod. 2014, 53, 78-84. [CrossRef]

38. Öztürk, E. Performance, emissions, combustion and injection characteristics of a diesel engine fuelled with canola oil-hazelnut soapstock biodiesel mixture. Fuel Process. Technol. 2015, 129, 183-191. [CrossRef]

39. Mofijur, M.; Masjuki, H.H.; Kalam, M.A.; Atabani, A.E.; Arbab, M.I.; Cheng, S.F.; Gouk, S.W. Properties and use of Moringa oleifera biodiesel and diesel fuel blends in a multi-cylinder diesel engine. Energy Convers. Manag. 2014, 82, 169-176. [CrossRef]

40. Syed, A.; Quadri, S.A.P.; Rao, G.A.P.; Mohd, W. Experimental investigations on DI (direct injection) diesel engine operated on dual fuel mode with hydrogen and mahua oil methyl ester (MOME) as injected fuels and effects of injection opening pressure. Appl. Therm. Eng. 2017, 114, 118-129. [CrossRef]

41. Rahman, M.M.; Rasul, M.G.; Hassan, N.M.S.; Azad, A.K.; Uddin, N. Effect of small proportion of butanol additive on the performance, emission, and combustion of Australian native first- and second-generation biodiesel in a diesel engine. Environ. Sci. Pollut. Res. 2017, 24, 22402-22413. [CrossRef]

42. Sharma, L.; Grover, N.K.; Bhardwaj, M.; Kaushal, I. Comparison of engine performance of mixed Jatropha and cottonseed derived biodiesel blends with conventional diesel. Int. J. Emerg. Technol. 2012, 3, $29-32$.

43. Özçelik, A.E.; Aydoğan, H.; Acaroğlu, M. Determining the performance, emission and combustion properties of camelina biodiesel blends. Energy Convers. Manag. 2015, 96, 47-57. [CrossRef]

44. Kalam, M.A.; Masjuki, H.H.; Jayed, M.H.; Liaquat, A.M. Emission and performance characteristics of an indirect ignition diesel engine fuelled with waste cooking oil. Energy 2011, 36, 397-402. [CrossRef] 
45. Pinto, A.C.; Guarieiro, L.L.N.; Rezende, M.J.C.; Ribeiro, N.M.; Torres, E.A.; Lopes, W.A.; Pereira, P.A.d.; de Andrade, J.B. Biodiesel: An overview. J. Braz. Chem. Soc. 2005, 16, 1313-1330. [CrossRef]

46. Dinesha, P.; Mohanan, P. Combined effect of oxygen enrichment and exhaust gas recirculation on the performance and emissions of a diesel engine fueled with biofuel blends. Biofuels 2018, 9, 45-51. [CrossRef]

47. Man, X.J.; Cheung, C.S.; Ning, Z.; Wei, L.; Huang, Z.H. Influence of engine load and speed on regulated and unregulated emissions of a diesel engine fueled with diesel fuel blended with waste cooking oil biodiesel. Fuel 2016, 180, 41-49. [CrossRef]

48. Kegl, B. Influence of biodiesel on engine combustion and emission characteristics. Appl. Energy 2011, 88, 1803-1812. [CrossRef]

(C) 2019 by the authors. Licensee MDPI, Basel, Switzerland. This article is an open access article distributed under the terms and conditions of the Creative Commons Attribution (CC BY) license (http://creativecommons.org/licenses/by/4.0/). 